\title{
Article \\ Comparison of Four Commercially Available Point-of-Care Tests to Detect Antibodies against Canine Parvovirus in Dogs
}

\author{
Michèle Bergmann ${ }^{1, *}$, Mike Holzheu ${ }^{2}$, Yury Zablotski ${ }^{1}$, Stephanie Speck ${ }^{3}$, Uwe Truyen ${ }^{3}$, \\ Reinhard K. Straubinger ${ }^{4}$ (D) and Katrin Hartmann ${ }^{1}$ (D) \\ 1 Clinic of Small Animal Medicine, Centre for Clinical Veterinary Medicine, LMU Munich, Veterinaerstrasse 13, \\ 80539 Munich, Germany; Y.Zablotski@med.vetmed.uni-muenchen.de (Y.Z.); hartmann@lmu.de (K.H.) \\ 2 Clinic of Small Animal Surgery and Reproduction, Centre for Clinical Veterinary Medicine, LMU Munich, \\ Veterinaerstrasse 13, 80539 Munich, Germany; M.Holzheu@medizinische-kleintierklinik.de \\ 3 Institute of Animal Hygiene and Veterinary Public Health, University of Leipzig, An den Tierkliniken 1, \\ 04103 Leipzig, Germany; stephanie@speck-kaysser.de (S.S.); truyen@vetmed.uni-leipzig.de (U.T.) \\ 4 Bacteriology und Mycology, Institute for Infectious Diseases and Zoonoses, Faculty of Veterinary Medicine, \\ LMU Munich, Veterinaerstrasse 13, 80539 Munich, Germany; \\ Reinhard.Straubinger@micro.vetmed.uni-muenchen.de \\ * Correspondence: n.bergmann@medizinische-kleintierklinik.de; Tel.: +49-(0)89-2180-2651
}

check for

updates

Citation: Bergmann, M.; Holzheu, M.; Zablotski, Y.; Speck, S.; Truyen, U.; Straubinger, R.K.; Hartmann, K. Comparison of Four Commercially Available Point-of-Care Tests to Detect Antibodies against Canine Parvovirus in Dogs. Viruses 2021, 13, 18. https://dx.doi.org/10.3390/ v13010018

Academic Editor: Tohru Suzuki Received: 8 December 2020 Accepted: 21 December 2020 Published: 23 December 2020

Publisher's Note: MDPI stays neutral with regard to jurisdictional claims in published maps and institutional affiliations.

Copyright: () 2020 by the authors. Licensee MDPI, Basel, Switzerland. This article is an open access article distributed under the terms and conditions of the Creative Commons Attribution (CC BY) license (https: / / creativecommons.org/ licenses/by/4.0/).

\begin{abstract}
Measuring antibodies to evaluate dogs' immunity against canine parvovirus (CPV) is useful to avoid unnecessary re-vaccinations. The study aimed to evaluate the quality and practicability of four point-of-care (POC) tests for detection of anti-CPV antibodies. The sera of 198 client-owned and 43 specific pathogen-free (SPF) dogs were included; virus neutralization was the reference method. Specificity, sensitivity, positive and negative predictive value (PPV and NPV), and overall accuracy (OA) were calculated. Specificity was considered to be the most important indicator for POC test performance. Differences between specificity and sensitivity of POC tests in the sera of all dogs were determined by McNemar, agreement by Cohen's kappa. Prevalence of anti-CPV antibodies in all dogs was 80\% (192/241); in the subgroup of client-owned dogs, it was 97\% (192/198); and in the subgroup of SPF dogs, it was $0 \%(0 / 43)$. FASTest ${ }^{\circledR}$ and CanTiCheck ${ }^{\circledR}$ were easiest to perform. Specificity was highest in the CanTiCheck ${ }^{\circledR}$ (overall dogs, 98\%; client-owned dogs, 83\%; SPF dogs, 100\%) and the TiterCHEK ${ }^{\circledR}$ (overall dogs, 96\%; client-owned dogs, 67\%; SPF dogs, 100\%); no significant differences in specificity were observed between the ImmunoComb ${ }^{\circledR}$, the TiterCHEK ${ }^{\circledR}$, and the CanTiCheck ${ }^{\circledR}$. Sensitivity was highest in the FASTest ${ }^{\circledR}$ (overall dogs, 95\%; client-owned dogs, 95\%) and the CanTiCheck ${ }^{\circledR}$ (overall dogs, 80\%; client-owned dogs, 80\%); sensitivity of the FASTest ${ }^{\circledR}$ was significantly higher compared to the one of the other three tests (McNemars $p$-value in each comparison: $<0.001)$. CanTiCheck ${ }^{\circledR}$ would be the POC test of choice when considering specificity and practicability. However, differences in the number of false positive results between CanTiCheck ${ }^{\circledR}$, TiterCHEK ${ }^{\circledR}$, and ImmunoComb ${ }^{\circledR}$ were minimal.
\end{abstract}

Keywords: POC test; in-house test; CPV; protection; vaccination; sensitivity; specificity; PPV; NP

\section{Introduction}

Canine parvovirus-2 (CPV-2) is a highly pathogenic virus, and protection is essential for all dogs [1,2]. Presence of antibodies against CPV in adult dogs suggests adequate immunity against disease [3,4]. Measurement of pre-vaccination antibodies against CPV is therefore useful to determine the specific immune status of an adult dog. If antibodies are present, unnecessary re-vaccinations, which potentially cause vaccine-associated adverse events, can be avoided [2,5]. Additionally, the measurement of antibodies can be used to determine whether dogs responded to vaccination, as well as for the management of disease outbreaks, e.g., in animal shelters [2,6,7].

Virus neutralization (VN) detects antibodies that neutralize infectious particles and prevent infection [8]. VN can be used to determine the level of anti-CPV antibody titers, 
but it can only be performed in specialized laboratories [8]. Thus, point-of-care (POC) tests would be a useful tool in practice, to assess whether a dog is potentially unprotected and requires re-vaccination.

Recently, four different POC tests became available on the market, for detection of anti-CPV antibodies in-house in veterinary practice (Table 1). It takes between 10 and 21 min to perform these tests.

Table 1. Manufacturers' instructions of the four point-of-care tests for detection of anti-canine parvovirus antibodies. Data on antibodies against canine distemper virus and canine adenovirus were not subjects of the present study.

\begin{tabular}{|c|c|c|c|c|}
\hline Point-of-Care Test & $\begin{array}{l}\text { ImmunoComb }^{\circledR} \text { Canine } \\
\text { VacciCheck, Enzyme-Linked } \\
\text { Immunosorbent Assay }\end{array}$ & $\begin{array}{c}\text { TiterCHEK }{ }^{\circledR} \mathrm{CDV}^{1} / \mathrm{CPV}^{2}, \\
\text { Enzyme-Linked } \\
\text { Immunosorbent Assay }\end{array}$ & $\begin{array}{c}\text { FASTest }^{\circledR} \mathrm{CDV}^{1}{ }^{1} \mathrm{CPV}^{2} \\
\mathrm{Ab}^{3}, \text { Lateral Flow } \\
\text { Immunoassay }^{2}\end{array}$ & $\begin{array}{l}\text { CanTiCheck }^{\circledR}, \\
\text { Lateral Flow } \\
\text { Immunoassay }\end{array}$ \\
\hline $\begin{array}{l}\text { Antibodies } \\
\text { Storage }\end{array}$ & $\begin{array}{c}\mathrm{CPV}^{2}, \mathrm{CDV}^{1}, \mathrm{CAV}^{4} \\
\text { refrigerated }\end{array}$ & $\begin{array}{c}\mathrm{CPV}^{2}, \mathrm{CDV}^{1} \\
\text { refrigerated }\end{array}$ & $\begin{array}{l}\mathrm{CPV}^{2}, \mathrm{CDV}^{1} \\
\text { at room temperature }\end{array}$ & $\begin{array}{c}\mathrm{CPV}^{2}, \mathrm{CDV}^{1} \\
\text { at room temperature }\end{array}$ \\
\hline Application & $\begin{array}{l}\text { after warming up to room } \\
\text { temperature }(60-120 \mathrm{~min})\end{array}$ & $\begin{array}{l}\text { after warming up to room } \\
\text { temperature }(60-120 \mathrm{~min})\end{array}$ & immediately & immediately \\
\hline $\begin{array}{c}\text { Time of performance } \\
\text { Test material }\end{array}$ & $\begin{array}{c}21 \text { min } \\
\text { serum }(5 \mu \mathrm{L}) \text {, plasma }(5 \mu \mathrm{L}) \text {, or } \\
\text { whole blood }(10 \mu \mathrm{L})\end{array}$ & $\begin{array}{c}20 \mathrm{~min} \\
\text { serum or plasma (each } 1 \mu \mathrm{L})\end{array}$ & $\begin{array}{l}10 \mathrm{~min} \\
\text { serum, plasma, or whole } \\
\text { blood (each } 5 \mu \mathrm{L})\end{array}$ & $\begin{array}{c}10 \min \\
\text { serum }(50 \mu \mathrm{L})\end{array}$ \\
\hline
\end{tabular}

The TiterCHEK ${ }^{\circledR}$ CDV /CPV (Zoetis) has been evaluated previously by three studies [9-11], and one of these studies compared its quality to that of the ImmunoComb ${ }^{\circledR}$ Canine VacciCheck (Biogal Laboratories) [10]. The FASTest ${ }^{\circledR}$ CPV-CDV (MEGACOR Diagnostik $\mathrm{GmbH}$ ) has been evaluated by only one study [12]. So far, there are no data (other than the manufacturers' information) on the CanTiCheck ${ }^{\circledR}$ (Fassisi Gesellschaft für Veterinärdiagnostik und Umweltanalysen $\mathrm{mbH}$ ).

The aim of this study was to compare the four commercially available POC tests detecting antibodies against CPV, concerning their practicability, specificity, sensitivity, positive predictive value (PPV), negative predictive value (NPV), and overall accuracy $(\mathrm{OA})$, using $\mathrm{VN}$ as the reference standard.

\section{Materials and Methods}

2.1. Sera

The protocol of this prospective study was accepted by the ethical committee of the LMU Munich, Germany (reference number 124-13-05-2018) on 18 July 2018.

Client-owned dogs $(n=198)$ that were presented to the Clinic of Small Animal Medicine, LMU, Munich, from June to August 2018, and that needed blood analyses for healthcare assessment or diagnostic purposes were included. The dogs' age ranged from 3 months to 16 years (median age was 9 years). Table 2 shows the dogs' signalment and health status.

In addition, 43 samples of specific pathogen-free (SPF) dogs that had never been vaccinated were included in the study. These stored samples were provided by the Institute of Animal Hygiene and Veterinary Public Health, University of Leipzig, and the Institute for Infectious Diseases and Zoonoses, LMU Munich. All samples were stored at $-80^{\circ} \mathrm{C}$, until testing. 
Table 2. Signalment and health status of the client-owned dogs.

\begin{tabular}{ccc}
\hline Variable & Category & Number of Dogs \\
\hline \multirow{2}{*}{ Breed } & Mixed breed & 47 \\
& Purebred & 151 \\
Sex & Female & 102 \\
Neutering status & Male & 96 \\
& Intact & 97 \\
& Neutered & 101 \\
& Healthy & 22 \\
Health status & Immune-mediated disorders & 1 \\
& Endocrine disorders & 8 \\
& Inflammatory/infectious diseases & 39 \\
& Neoplasia & 49 \\
& Neurologic disease & 18 \\
& Cardiac disease & 24 \\
& Orthopedic problems & 22 \\
\hline
\end{tabular}

\subsection{Measurement of Anti-CPV Antibodies by VN}

Crandell Rees feline kidney (CRFK) cells were maintained in Dulbecco's MEM (Merck Millipore, Darmstadt, Germany) supplemented with 5\% fetal calf serum (FCS; Merck Millipore), $1 \%$ nonessential amino acids (Merck Millipore), and 1\% penicillin-streptomycin (Merck Millipore), at $37^{\circ} \mathrm{C}$, with $5 \% \mathrm{CO}_{2}$. Serum samples underwent heat-inactivation (56 ${ }^{\circ} \mathrm{C}$ for $30 \mathrm{~min}$ ). A $100 \mu \mathrm{L}$ aliquot of each serum was pre-diluted (1:5) in phosphatebuffered saline (PBS; pH 7.2) and further serially diluted at steps of 1:2. Each dilution was mixed with an equal volume of CPV-2 strain vBI 265 (200 median tissue culture infective dose per $0.1 \mathrm{~mL}$ ) and incubated at $37^{\circ} \mathrm{C}$ for $60 \mathrm{~min}$. Subsequently, CRFK cells seeded in 96-well microtiter plates were inoculated with $100 \mu \mathrm{L}$ of these serum/virus mixtures. Plates were incubated for five days, at $37^{\circ} \mathrm{C}$, with $5 \% \mathrm{CO}_{2}$. Thereafter, culture supernatants were taken off, and cells were fixed by using acetone (>99.9\%)/methanol (>99.9\%) 1:1 (vol/vol) at $-20^{\circ} \mathrm{C}$ for $20 \mathrm{~min}$. Subsequently, the fixation medium was discarded, and cells were allowed to dry for $30 \mathrm{~min}$. After a single PBS-washing step, blocking was performed in PBS, with 3\% FCS, to reduce non-specific binding and background signal. For virus staining, an anti-CPV monoclonal antibody [13] was added, and samples were incubated at $37^{\circ} \mathrm{C}$ for 6-8 hours. After washing with PBS, a fluorescein isothiocyanate-conjugated goat-anti-mouse IgG (H + L) conjugate (Dianova, Hamburg, Germany) was added (room temperature, overnight). Samples were analyzed by using a Leica DMIL fluorescence microscope. The positive control serum was obtained from a privately owned vaccinated dog. All samples were run in duplicate in the same test. A titer $<10$ was considered negative.

\subsection{Measurement of Anti-CPV Antibodies by POC Tests}

The four POC tests (ImmunoComb ${ }^{\circledR}$ Canine Vaccicheck; TiterCHEK ${ }^{\circledR} \mathrm{CDV} / \mathrm{CPV}$; FASTest ${ }^{\circledR}$ CPV-CDV, CanTiCheck ${ }^{\circledR}$ ) measure antibodies against CPV, as well as against canine distemper virus (CDV) $\left(\right.$ TiterCHEK $^{\circledR}$; FASTest ${ }^{\circledR}$, CanTiCheck ${ }^{\circledR}$ ) or against CPV, $\mathrm{CDV}$, and canine adenovirus (CAV) $\left(\operatorname{ImmunoComb}{ }^{\circledR}\right)$; data on antibodies against CDV and CAV-1 were not the subject of the present study.

All tests were analyzed according to manufacturers' instructions, by an independent person who was blinded to the results of the VN.

The ImmunoComb ${ }^{\circledR}$ and the TiterCHEK ${ }^{\circledR}$ are enzyme-linked immunosorbent assays; FASTest ${ }^{\circledR}$ and CanTiCheck ${ }^{\circledR}$ are lateral flow immunoassays (immunochromatography assays). Test results were regarded positive, as defined by the manufacturers' instructions.

\subsection{Statistical Analysis}

The sample-size calculation for the sera of client-owned dogs was based on the assumption of a prevalence of $70 \%[5,14,15]$ and a $5 \%$ desired level of significance [16]. 
To achieve a power of $\geq 80 \%$ (based on results of Gray et al., 2012 [9] and Litster et al., 2012 [11]), at least 147 samples were required. Results of the four POC tests were compared to the results of the VN assay, for determination of the diagnostic quality of each assay. Sensitivity, specificity, PPV, NPV, and OA were calculated for all dogs, as well as for the subgroup of client-owned dogs and for the subgroup of SPF dogs. Specificity was regarded as the most important parameter for the quality of the tests. McNemar's test was used for the paired study design, to determine significant differences in specificity and sensitivity between the POC tests for all dogs. To assess the agreement of the results among the four POC tests, Cohen's Kappa statistic was used. The $p$-values $<0.05$ were considered significant.

\section{Results}

\subsection{Prevalence of Anti-CPV Antibodies Determined by VN}

The prevalence of antibodies, when considering the sera of all dogs, was $80 \%(192 / 241$; 95\% CI: 74-85). Antibodies against CPV were present in 97\% (192/198; 95\% CI: 93-99) of the client-owned dog population. None of the SPF dogs had anti-CPV antibodies (0/43; 95\% CI: 0-10).

\subsection{Practicability of the POC Tests}

Results of all serum samples in all of the four POC tests (TiterCHEK ${ }^{\circledR}$, FASTest ${ }^{\circledR}$, ImmunoComb ${ }^{\circledR}$, and CanTiCheck ${ }^{\circledR}$ ) could clearly be classified as positive or negative. According to the manufacturers' instructions, the FASTest ${ }^{\circledR}$ and the CanTiCheck ${ }^{\circledR}$ were stored at room temperature. For testing, 5 and $50 \mu \mathrm{L}$ of serum were necessary, respectively. In both tests, results were available after $10 \mathrm{~min}$. The TiterCHEK ${ }^{\circledR}$ and the ImmunoComb ${ }^{\circledR}$ were refrigerated, and it was necessary to bring them to room temperature before measurement, according to the manufacturers' recommendations; after the warm-up period, the tests delivered results after an additional 20 and $21 \mathrm{~min}$, respectively. For testing, 1 and $5 \mu \mathrm{L}$ of serum were necessary, respectively.

\subsection{Measurement of Anti-CPV Antibodies by POC Tests}

Sensitivity, specificity, PPV, NPV, and OA of the four POC tests, when compared to $\mathrm{VN}$ as the reference standard, in all groups of dogs are shown in Tables 3 and 4. Specificity was highest in the CanTiCheck ${ }^{\circledR}$ (overall dogs, 98\%; client-owned dogs, 83\%; SPF dogs, 100\%) and the TiterCHEK ${ }^{\circledR}$ (overall dogs, 96\%; client-owned dogs, 67\%; SPF dogs, $100 \%)$; no significant differences in specificity were observed between the ImmunoComb ${ }^{\circledR}$, the TiterCHEK ${ }^{\circledR}$, and the CanTiCheck ${ }^{\circledR}$ when considering all dogs (Table 5). Sensitivity was highest in the FASTest ${ }^{\circledR}$ (overall dogs, 95\%; client-owned dogs, 95\%) and the CanTiCheck ${ }^{\circledR}$ (overall dogs, $80 \%$; client-owned dogs, $80 \%$ ); sensitivity of the FASTest ${ }^{\circledR}$ was significantly higher compared to the one of the other three tests (McNemars $p$-value in each comparison: $<0.001$ ), sensitivity of the CanTiCheck ${ }^{\circledR}$ was significantly higher compared to the one of the TiterCHEK ${ }^{\circledR}$ (McNemars $p$-value: $\left.<0.001\right)$. Table 6 shows the agreement of the POC test results in all dogs. TiterCHEK ${ }^{\circledR}$ and FASTest ${ }^{\circledR}$ had the same result in $164 / 241$ (68\%) samples, TiterCHEK ${ }^{\circledR}$ and ImmunoComb ${ }^{\circledR}$ in 166/241 (69\%), FASTest ${ }^{\circledR}$ and ImmunoComb ${ }^{\circledR}$ in $171 / 241(71 \%)$, CanTiCheck ${ }^{\circledR}$ and ImmunoComb ${ }^{\circledR}$ in 186/241 (77\%), CanTiCheck ${ }^{\circledR}$ and TiterCHEK $^{\circledR}$ in 185/241 (77\%), and CanTiCheck ${ }^{\circledR}$ and FASTest ${ }^{\circledR}$ in 196/241 (81\%) samples. 


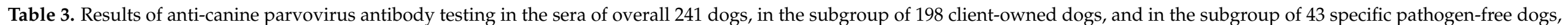
and comparison of the four point-of-care tests, using $\mathrm{VN}$ as the reference standard.

\begin{tabular}{|c|c|c|c|c|c|c|c|c|}
\hline & $\begin{array}{c}\text { ImmunoComb }^{\circledR} \\
\text { Negative }\end{array}$ & $\begin{array}{c}\text { ImmunoComb }^{\circledR} \\
\text { Positive }\end{array}$ & $\begin{array}{c}\text { TiterCHEK }^{\circledR} \\
\text { Negative }\end{array}$ & $\begin{array}{c}\text { TiterCHEK }^{\circledR} \\
\text { Positive }\end{array}$ & $\begin{array}{l}\text { FASTest }^{\circledR} \\
\text { Negative }\end{array}$ & $\begin{array}{c}\text { FASTest }^{\circledR} \\
\text { Positive }\end{array}$ & $\begin{array}{c}\text { CanTiCheck }^{\circledR} \\
\text { Negative }\end{array}$ & $\begin{array}{c}\text { CanTiCheck }^{\circledR} \\
\text { Positive }\end{array}$ \\
\hline \multicolumn{9}{|c|}{ Results in sera of all 241 dogs (client-owned dogs and specific pathogen free dogs) } \\
\hline $\begin{array}{l}\mathrm{VN}^{1} \text { negative } \\
(<10)(n=49)\end{array}$ & $\begin{array}{c}46 \text { true } \\
\text { negatives }\end{array}$ & $\begin{array}{l}3 \text { false } \\
\text { positives }\end{array}$ & $\begin{array}{c}47 \text { true } \\
\text { negatives }\end{array}$ & $\begin{array}{c}2 \text { false } \\
\text { positives }\end{array}$ & $\begin{array}{c}36 \text { true } \\
\text { negatives }\end{array}$ & $\begin{array}{l}13 \text { false } \\
\text { positives }\end{array}$ & $\begin{array}{c}48 \text { true } \\
\text { negatives }\end{array}$ & $\begin{array}{c}1 \text { false } \\
\text { positive }\end{array}$ \\
\hline $\begin{array}{l}\mathrm{VN}^{1} \text { positive } \\
(\geq 10)(n=192)\end{array}$ & $\begin{array}{c}57 \text { false } \\
\text { negatives }\end{array}$ & $\begin{array}{l}135 \text { true } \\
\text { positives }\end{array}$ & $\begin{array}{l}71 \text { false } \\
\text { negatives }\end{array}$ & $\begin{array}{l}121 \text { true } \\
\text { positives }\end{array}$ & $\begin{array}{c}9 \text { false } \\
\text { negatives }\end{array}$ & $\begin{array}{l}183 \text { true } \\
\text { positives }\end{array}$ & $\begin{array}{c}38 \text { false } \\
\text { negatives }\end{array}$ & $\begin{array}{l}154 \text { true } \\
\text { positives }\end{array}$ \\
\hline \multicolumn{9}{|c|}{ Results in sera of 198 client-owned dogs } \\
\hline $\begin{array}{l}\mathrm{VN}^{1} \text { negative } \\
(<10)(n=6)\end{array}$ & $\begin{array}{c}3 \text { true } \\
\text { negatives }\end{array}$ & $\begin{array}{c}3 \text { false } \\
\text { positives }\end{array}$ & $\begin{array}{c}4 \text { true } \\
\text { negatives }\end{array}$ & $\begin{array}{c}2 \text { false } \\
\text { positives }\end{array}$ & $\begin{array}{c}2 \text { true } \\
\text { negatives }\end{array}$ & $\begin{array}{c}4 \text { false } \\
\text { positives }\end{array}$ & $\begin{array}{c}5 \text { true } \\
\text { negatives }\end{array}$ & $\begin{array}{c}1 \text { false } \\
\text { positives }\end{array}$ \\
\hline $\begin{array}{l}\mathrm{VN}^{1} \text { positive } \\
(\geq 10)(n=192)\end{array}$ & $\begin{array}{c}57 \text { false } \\
\text { negatives }\end{array}$ & $\begin{array}{l}135 \text { true } \\
\text { positives }\end{array}$ & $\begin{array}{l}71 \text { false } \\
\text { negatives }\end{array}$ & $\begin{array}{l}121 \text { true } \\
\text { positives }\end{array}$ & $\begin{array}{c}9 \text { false } \\
\text { negatives }\end{array}$ & $\begin{array}{l}183 \text { true } \\
\text { positives }\end{array}$ & $\begin{array}{c}38 \text { false } \\
\text { negatives }\end{array}$ & $\begin{array}{l}154 \text { true } \\
\text { positives }\end{array}$ \\
\hline \multicolumn{9}{|c|}{ Results in sera of 43 specific pathogen-free dogs } \\
\hline $\begin{array}{l}\mathrm{VN}^{1} \text { negative } \\
(<10)(n=43)\end{array}$ & $\begin{array}{c}43 \text { true } \\
\text { negatives }\end{array}$ & $\begin{array}{c}0 \text { false } \\
\text { positives }\end{array}$ & $\begin{array}{l}43 \text { true } \\
\text { negatives }\end{array}$ & $\begin{array}{l}0 \text { false } \\
\text { positives }\end{array}$ & $\begin{array}{c}34 \text { true } \\
\text { negatives }\end{array}$ & $\begin{array}{c}9 \text { false } \\
\text { positives }\end{array}$ & $\begin{array}{c}43 \text { true } \\
\text { negatives }\end{array}$ & $\begin{array}{l}0 \text { false } \\
\text { positives }\end{array}$ \\
\hline $\mathrm{VN}^{1}$ positive & 0 false & 0 true & 0 false & 0 true & 0 false & 0 true & 0 false & 0 true \\
\hline$(\geq 10)(n=0)$ & negatives & positives & negatives & positives & negatives & positives & negatives & positives \\
\hline
\end{tabular}

${ }^{1} \mathrm{VN}$, virus neutralization. 


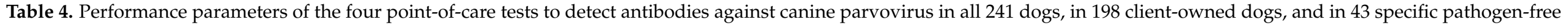

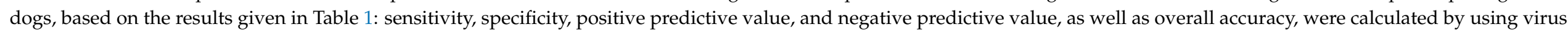

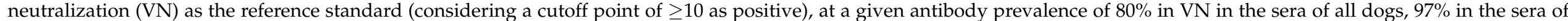
client-owned dogs, and $0 \%$ in the sera of specific pathogen-free dogs.

\begin{tabular}{|c|c|c|c|c|}
\hline Point-of-Care Tests & ImmunoComb $^{\circledR}$ & TiterCHEK $^{\circledR}$ & FASTest $^{\circledR}$ & CanTiCheck $^{\circledR}$ \\
\hline \multicolumn{5}{|c|}{$\begin{array}{l}\text { Results in sera of all } 241 \text { dogs (client-owned dogs and specific pathogen free dogs) } \\
\text { (prevalence of antibodies in virus neutralization: } 80 \% \text { ) }\end{array}$} \\
\hline Sensitivity ${ }^{1} \%\left(95 \% \mathrm{CI}^{2} \%\right)$ & $70(63-77)$ & $63(56-70)$ & $95(91-98)$ & $80(74-86)$ \\
\hline Positive predictive value $4 \%\left(95 \% \mathrm{CI}^{2} \%\right)$ & $98(94-100)$ & $98(94-100)$ & $93(89-96)$ & $99(96-100)$ \\
\hline Negative predictive value $5 \%\left(95 \% \mathrm{CI}^{2} \%\right)$ & $45(35-55)$ & $40(31-49)$ & $80(65-90)$ & $56(45-67)$ \\
\hline Overall accuracy $6 \%\left(95 \% \mathrm{CI}^{2} \%\right)$ & $75(69-80)$ & $70(63-75)$ & $91(87-94)$ & $84(79-88)$ \\
\hline \multicolumn{5}{|c|}{ Results in sera of 198 client-owned dogs (prevalence of antibodies in virus neutralization: $97 \%$ ) } \\
\hline Specificity ${ }^{3} \%\left(95 \% \mathrm{CI}^{2} \%\right)$ & $50(12-88)$ & $67(22-96)$ & $33(4-78)$ & $83(36-100)$ \\
\hline Positive predictive value $4 \%\left(95 \% \mathrm{CI}^{2} \%\right)$ & $98(94-100)$ & $98(94-100)$ & $98(95-99)$ & $99(96-100)$ \\
\hline Negative predictive value $5 \%\left(95 \% \mathrm{CI}^{2} \%\right)$ & $5(1-14)$ & $5(1-13)$ & $18(2-52)$ & $12(4-25)$ \\
\hline Overall accuracy $6 \%\left(95 \% \mathrm{CI}^{2} \%\right)$ & $70(63-76)$ & $63(56-70)$ & $93(89-96)$ & $80(74-86)$ \\
\hline \multicolumn{5}{|c|}{ Results in sera of 43 specific pathogen free dogs (prevalence of antibodies in virus neutralization: $0 \%$ ) } \\
\hline Sensitivity ${ }^{1} \%\left(95 \% \mathrm{CI}^{2} \%\right)$ & n.d. ${ }^{7}$ & n.d. ${ }^{7}$ & n. d. ${ }^{7}$ & n.d. ${ }^{7}$ \\
\hline Specificity ${ }^{3} \%\left(95 \% \mathrm{CI}^{2} \%\right)$ & 100 & 100 & $79(64-90)$ & 100 \\
\hline Positive predictive value $4 \%\left(95 \% \mathrm{CI}^{2} \%\right)$ & n.d. ${ }^{7}$ & n.d. ${ }^{7}$ & n.d. ${ }^{7}$ & n.d. ${ }^{7}$ \\
\hline Negative predictive value $5 \%\left(95 \% \mathrm{CI}^{2} \%\right)$ & 100 & 100 & 100 & 100 \\
\hline
\end{tabular}

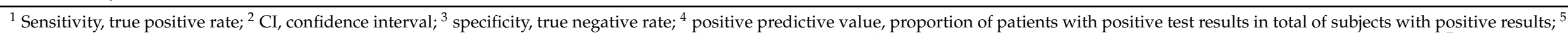

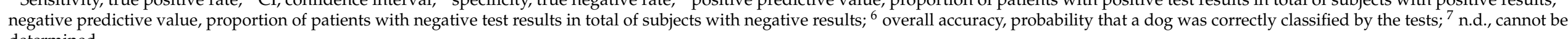
determined. 
Table 5. Results of McNemar's statistic to determine differences between specificity and sensitivity of the binary point-ofcare tests in all dogs.

\begin{tabular}{|c|c|c|c|c|}
\hline Point-of-Care Test & Specificity & $\begin{array}{l}\text { McNemar's } p \text {-Value for } \\
\text { Comparison of Specificity }\end{array}$ & Sensitivity & $\begin{array}{l}\text { McNemar's } p \text {-Value for } \\
\text { Comparison of Sensitivity }\end{array}$ \\
\hline $\begin{array}{c}\text { TiterCHEK }^{\circledR} \\
\text { FASTest }^{\circledR}\end{array}$ & $\begin{array}{l}96 \% \\
73 \%\end{array}$ & $<0.001$ & $\begin{array}{l}63 \% \\
95 \%\end{array}$ & $<0.001$ \\
\hline $\begin{array}{c}\text { TiterCHEK }^{\circledR} \\
\text { ImmunoComb }^{\circledR}\end{array}$ & $\begin{array}{l}96 \% \\
94 \%\end{array}$ & 0.564 & $\begin{array}{l}63 \% \\
70 \%\end{array}$ & 0.099 \\
\hline $\begin{array}{c}\text { FASTest }^{\circledR} \\
\text { ImmunoComb }^{\circledR}\end{array}$ & $\begin{array}{l}73 \% \\
94 \%\end{array}$ & 0.008 & $\begin{array}{l}95 \% \\
70 \%\end{array}$ & $<0.001$ \\
\hline $\begin{array}{c}\text { ImmunoComb }^{\circledR} \\
\text { CanTiCheck }^{\circledR}\end{array}$ & $\begin{array}{l}94 \% \\
98 \%\end{array}$ & 0.317 & $\begin{array}{l}70 \% \\
80 \%\end{array}$ & 0.008 \\
\hline $\begin{array}{l}\text { CanTiCheck }^{\circledR} \\
\text { TiterCHEK }^{\circledR}\end{array}$ & $\begin{array}{l}98 \% \\
96 \%\end{array}$ & 0.317 & $\begin{array}{l}80 \% \\
63 \%\end{array}$ & $<0.001$ \\
\hline $\begin{array}{l}\text { CanTiCheck }^{\circledR} \\
\text { FASTest }^{\circledR}\end{array}$ & $\begin{array}{l}98 \% \\
73 \%\end{array}$ & $<0.001$ & $\begin{array}{l}80 \% \\
95 \%\end{array}$ & $<0.001$ \\
\hline
\end{tabular}

Table 6. Agreement of the results of the four point-of-care tests, using Cohen's kappa statistic in all dogs.

\begin{tabular}{|c|c|c|c|c|}
\hline \multirow{2}{*}{ Point-of-Care Test } & \multirow{2}{*}{ Agreement of Positive Results } & \multirow{2}{*}{ Agreement of Negative Results } & \multicolumn{2}{|c|}{ Kappa Coefficient } \\
\hline & & & $95 \% \mathrm{CI}^{1}$ & $p$-Value \\
\hline $\begin{array}{c}\text { TiterCHEK }^{\circledR} \\
\text { FASTest }^{\circledR}\end{array}$ & 121 & 43 & $\begin{array}{c}0.35 \\
(0.23-0.47)\end{array}$ & $<0.001$ \\
\hline $\begin{array}{c}\text { TiterCHEK }^{\circledR} \\
\text { ImmunoComb }^{\circledR}\end{array}$ & 93 & 73 & $\begin{array}{c}0.38 \\
(0.26-0.49)\end{array}$ & $<0.001$ \\
\hline $\begin{array}{c}\text { FASTest }^{\circledR} \\
\text { ImmunoComb }^{\circledR}\end{array}$ & 132 & 39 & $\begin{array}{c}0.36 \\
(0.23-0.49)\end{array}$ & $<0.001$ \\
\hline $\begin{array}{c}\text { ImmunoComb }^{\circledR} \\
\text { CanTiCheck }^{\circledR}\end{array}$ & 119 & 67 & $\begin{array}{c}0.52 \\
(0.41-0.63)\end{array}$ & $<0.001$ \\
\hline $\begin{array}{l}\text { CanTiCheck }^{\circledR} \\
\text { TiterCHEK }^{\circledR}\end{array}$ & 111 & 74 & $\begin{array}{c}0.53 \\
(0.43-0.64)\end{array}$ & $<0.001$ \\
\hline $\begin{array}{c}\text { CanTiCheck }^{\circledR} \\
\text { FASTest }^{\circledR}\end{array}$ & 153 & 43 & $\begin{array}{c}0.54 \\
(0.43-0.66)\end{array}$ & $<0.001$ \\
\hline
\end{tabular}

\footnotetext{
${ }^{1} \mathrm{CI}$, confidence interval.
}

Statistical analysis revealed a moderate agreement in the results of all dogs between the CanTiCheck ${ }^{\circledR}$ and TiterCHEK ${ }^{\circledR}, \mathrm{k}=0.53$; between the CanTiCheck ${ }^{\circledR}$ and the ImmunoComb ${ }^{\circledR}, \mathrm{k}=0.52$; and between CanTiCheck ${ }^{\circledR}$ and the FASTest ${ }^{\circledR}, \mathrm{k}=0.54$. Agreement among the other POC tests was fair (Table 6). Table 7 shows the subgroups of VN (virus neutralization) test results and the respective results of the four POC (point-of-care) tests for the detection of antibodies against CPV (canine parvovirus) in all dogs. 
Table 7. Subgroups of virus neutralization test results and the respective results of the four point-ofcare tests for the detection of antibodies against canine parvovirus all dogs.

\begin{tabular}{cccccc}
\hline VN $^{1}$ & ImmunoComb $^{\circledR}$ & TiterCHEK $^{\circledR}$ & FASTest $^{\circledR}$ & CanTiCheck $^{\circledR}$ & Number of Samples \\
\hline+ & + & + & + & + & 87 \\
+ & + & + & + & - & 4 \\
+ & - & + & + & - & 6 \\
+ & - & - & + & - & 12 \\
+ & - & - & - & - & 4 \\
+ & + & - & + & - & 9 \\
+ & - & + & + & + & 12 \\
+ & - & - & - & + & 1 \\
+ & + & + & - & + & 1 \\
+ & + & - & + & - & 31 \\
+ & + & - & - & + & 2 \\
+ & + & + & + & + & 22 \\
+ & - & - & + & - & 11 \\
- & - & + & + & - & 2 \\
- & + & - & - & - & 1 \\
- & + & + & + & + & 34 \\
- & - & - & - & - & \\
- & - & & - & & \\
\hline
\end{tabular}

${ }^{1} \mathrm{VN}$, virus neutralization.

\section{Discussion}

Although disease caused by CPV infection is rare in Northern and Central European countries today, the risk of spread of CPV via the import of dogs from Southern or Eastern Europe is still high $[17,18]$. Thus, all dogs should be protected against CPV infection at any time $[2,8]$. Detection of anti-CPV antibodies (at any level) is predictive for protection in adult dogs that have been vaccinated or infected previously [19]. Therefore, measurement of antibodies against CPV can be used to evaluate dogs' individual immune status [2,8]. Reference tests to detect antibody titers, such as VN, have to be performed in specialized laboratories. This is inconvenient for healthcare appointments at the veterinarian, because the decision whether a dog should be vaccinated or not should ideally be made at the veterinarian's practice, during the appointment. Thus, fast and reliable POC tests that can easily be performed in practice would be desirable. In Europe, four POC tests are available for measuring anti-CPV antibodies since recently. This is the first comparison study that evaluated and compared all four tests.

The FASTest ${ }^{\circledR}$ and the CanTiCheck ${ }^{\circledR}$ were the most practicable. Both tests can be stored at room temperature and do not need to be warmed up before testing, which makes the procedure less time-consuming and avoids incorrect handling. In addition, both tests were unproblematic to perform, as buffered-mixed serum can be easily applied to the test kit, and, thus, tests can be carried out by the veterinarian, without requiring any additional lab-trained staff.

Testing with the TiterCHEK ${ }^{\circledR}$ and the ImmunoComb ${ }^{\circledR}$ was more time-consuming compared to the FASTest ${ }^{\circledR}$ and the CanTiCheck ${ }^{\circledR}$, and the test procedures included several mixing steps, making these tests more laborious and less practicable.

For assessing performance of the pre-vaccination antibody POC tests, high specificity (and thus, low number of false positive test results) is most important. Dogs with a false positive result would not receive a re-vaccination, although possibly not being protected from infection at the time of the test, and this scenario has to be avoided. The CanTiCheck ${ }^{\circledR}$ had the highest specificity and was very practicable. However, it has to be realized that differences regarding the number of false positive results of the CanTiCheck ${ }^{\circledR}$ (one false positive), TiterCHEK ${ }^{\circledR}$ (two false positives), and the ImmunoComb ${ }^{\circledR}$ (three false positives) were minimal. The large variations in specificity between the POC tests in client-owned dogs from the present study are caused by the very low number of antibody-negative samples, which limits the possibility to assess the POC tests. However, this population 
mirrors exactly the epidemiological situation in which the tests are used in practice, as all dogs entering the hospital in which blood was drawn for various reasons were randomly included, and the aim of the study was to evaluate the POC tests under "normal" conditions in the field. The extremely high prevalence (97\%) in client-owned dogs in the present study still was unexpected and is in the upper range of what has been reported in previous studies of neighboring areas (from 66\% [14] up to 99\% [5,20-22]). Such a high prevalence raises the question if it is required to test for anti-CPV antibodies at all, since nearly all dogs were protected. Possibly, the goal of a POC tests should therefore be to specifically find individual dogs that might still be unprotected, e.g., due to immunosuppression. However, as only very few antibody-negative dogs were present in the group of clientowned dogs, the sera from SPF dogs lacking antibodies against CPV were tested, to further evaluate specificity of the POC tests. Three of the POC tests (CanTiCheck ${ }^{\circledR}$, TiterCHEK $^{\circledR}$, and ImmunoComb ${ }^{\circledR}$ ) delivered no false positive results, thus confirming that all POC tests (except the Fastest ${ }^{\circledR}$ ) had a high specificity.

So far, there are no data from independent studies on the CanTiCheck ${ }^{\circledR}$. Diagnostic performance of the test in all dogs in the present study was good (specificity, $98 \%$; sensitivity, $80 \%$ ), but not as good as declared by the manufacturer (specificity: $99.9 \%$; sensitivity: 98.1\%) [23]. The TiterCHEK ${ }^{\circledR}$ CDV /CPV has been evaluated by three independent studies in field dogs before [9-11]. The specificity of the TiterCHEK ${ }^{\circledR}$ in the present study of the client-owned dog population (67\%) was remarkably lower when compared to the former studies which examined samples of dogs from shelters and found specificities of 94\% [11], 98\% [9], and even 100\% [10], with a prevalence of anti-CPV antibodies of $84 \%$ [11], 67\% [9], and 85\% [10], respectively. Specificity of the ImmunoComb ${ }^{\circledR}$ was $81 \%$ in a study of Kim and colleagues (2017), compared to 50\% in client-owned dogs in the present study. The FASTest ${ }^{\circledR}$ has been evaluated in one study, and specificity was $94 \%$ with an anti-CPV antibody prevalence of 57\% [12] compared to $33 \%$ in client-owned dogs in the present study. The reason for the lower specificities of the TiterCHEK ${ }^{\circledR}$, the ImmunoComb ${ }^{\circledR}$, and the FASTest ${ }^{\circledR}$ in the present study, as compared to the previous studies, might be due to modifications to the tests by the manufacturer, with the aim of increasing the sensitivity of the tests [11]. Different batch qualities or even differences in the tests between the USA and Germany could also be possible explanations for these discrepancies. However, it also has to be considered that the specificities found in the present study do not necessarily differ markedly compared with those determined by previous studies, when taking the low number of VN-negative samples and thus the wide confidence intervals for specificity in the present study into account. When assessing specificities of the tests using the sera of all dogs (client-owned and SPF dogs), the results are more in line with the ones from the previous studies.

Other reasons for the discordance between the test results in the above mentioned studies [9-11], as well as the manufacturer's declaration concerning diagnostic performance of the tests versus the results of the present study, could theoretically be invalid $\mathrm{VN}$ results (e.g., false negative results). However, the discrepancies between the POC tests themselves and absence of a good agreement in statistical analysis clearly imply false results in the POC tests and not in the VN (Table 7). In addition, there was not even one sample that was positive in all four POC tests and negative in VN. Moreover, the VN results were not solely based on cytopathic effects, as the VN assay was combined with an indirect immunofluorescence staining, which allows for the detection of CPV particles within the nuclei of infected cells, hence, avoiding invalid VN results.

In the present study, VN was used for measurement of anti-CPV antibodies. Hemagglutination inhibition (HI) can alternatively be performed. While VN is based on the cytopathic effect of parvoviruses, HI evaluates the antibodies' ability to bind and agglutinate certain erythrocytes. In general, both tests are first-class correlated with protection, since they directly examine the biological effect of the antibodies [24] and are superior to other detection methods, such as the enzyme-linked immunosorbent assay or the indirect immunofluorescence test [25]. In comparison to HI, VN can be of advantage when testing 
samples containing CPV strains without hemagglutinating properties which have been described to occur [26]. In addition, $\mathrm{VN}$ is considered to have a higher sensitivity for detecting lower antibody titers and/or even antibodies after infection with new antigenic variants [27].

The PPV was high in all four POC tests in client-owned dogs, which was certainly influenced by the high antibody prevalence in the study population (Table 3). The PPV predicts the likelihood that a dog with a positive test result is antibody-positive and protected against disease and thus can be used to determine how reliably a positive result agrees with reality. However, it must be considered that the PPV is highly prevalencedependent, and it decreases with decreasing antibody prevalence. In the present study, PPVs of the POC tests in client-owned dogs were nearly identical to the given antibody prevalence $(97 \%)$. When testing with sera from SPF dogs only, three of the POC tests $\left(\right.$ CanTiCheck $^{\circledR}$, TiterCHEK ${ }^{\circledR}$, and ImmunoComb ${ }^{\circledR}$ ) had a specificity of $100 \%$, and only the Fastest ${ }^{\circledR}$ delivered false positive results.

On the other hand, the FASTest ${ }^{\circledR}$ showed best results in sensitivity. A test lacking sensitivity means that protected dogs will have a negative test result and would be vaccinated unnecessarily, which is, however, not a severe problem. At the moment, this happens anyway for many dogs which receive the recommended triennial re-vaccinations (or even yearly re-vaccinations).

For use in veterinary practice, POC tests with the highest specificity (TiterCHEK ${ }^{\circledR}$, CanTiCheck ${ }^{\circledR}$, and ImmunoComb ${ }^{\circledR}$ ) should be recommended. When comparing these tests with regard to other performance parameters, the CanTiCheck ${ }^{\circledR}$ had a significantly higher sensitivity than the other tests and a better practicability; therefore, it should be considered to be the test of choice. Overall, however, modifications of all tests would be recommended to aim a higher specificity, even if this would lead to a lower sensitivity, which is not as important for the setting in which the test will be used.

The limitation of the study is the low number of antibody-negative samples in the client-owned dogs. To overcome this limitation, the sera of 43 SPF dogs were included, even though specific pathogen-free animals do not reflect the epidemiological conditions in the field. The use of VN as the reference standard in the present study, and not HI, makes the comparison between the results of the present study and those of previous studies that have used HI more difficult.

\section{Conclusions}

When considering specificity, which is most important for avoiding lack of vaccination in an unprotected dog, as well as practicability, the CanTiCheck ${ }^{\circledR}$ would be the POC test of choice. Except for the FASTest ${ }^{\circledR}$, differences regarding number of false positive results were minimal (using sera from client-owned dogs in the field) or absent (using sera from SPF dogs). Nevertheless, modifications of all tests would be recommended to aim for higher specificity.

Author Contributions: Conceptualization K.H., and M.B.; methodology, M.B., M.H., S.S., and U.T.; validation Y.Z.; formal analysis Y.Z., and M.B.; investigation M.B.; resources K.H., R.K.S., and U.T.; data curation M.B.; writing —original draft preparation M.B.; writing—review and editing, K.H., S.S., U.T., Y.Z., M.H., R.K.S., and M.B.; visualization M.B.; supervision K.H.; project administration M.B., S.S., and U.T.; and funding acquisition K.H. All authors have read and agreed to the published version of the manuscript.

Funding: This research received no external financial funding.

Acknowledgments: We thank Nadja Leinecker of the Institute of Animal Hygiene and Veterinary Public Health, University of Leipzig, for her assistance in the performance of the VN assays. 
Conflicts of Interest: Katrin Hartmann has given talks for MSD, Boehringer Ingelheim, and IDEXX. Katrin Hartmann and Michèle Bergmann participated in research funded by or using products from MSD, Merial, Boehringer, Zoetis, Megacor, Biogal, and Scil. There is no commercial conflict of interest, as the information generated here is solely for scientific dissemination.

\section{References}

1. Welborn, L.V.; DeVries, J.G.; Ford, R.; Franklin, R.T.; Hurley, K.F.; McClure, K.D.; Paul, M.A.; Schultz, R.D. AAHA canine vaccination guidelines. J. Am. Anim. Hosp. Assoc. 2011, 47, 1-42. [PubMed]

2. Day, M.J.; Karkare, U.; Schultz, R.D.; Squires, R.; Tsujimoto, H. Recommendations on vaccination for Asian small animal practitioners: A report of the WSAVA Vaccination Guidelines Group. J. Small Anim. Pract. 2015, 56, 77-95. [CrossRef] [PubMed]

3. Greene, C.E.; Decaro, N. Canine viral enteritis. In Infectious Diseases of the Dog and Cat; Skyes, J.E., Greene, C.E., Eds.; Saunders Elsevier: St. Louis, MO, USA, 2012; pp. 67-75.

4. Greene, C.E.; Levy, J. Immunoprophylaxis. In Infectious Diseases of the Dog and Cat; Skyes, J.E., Greene, C.E., Eds.; Saunders Elsevier: St. Louis, MO, USA, 2012; pp. 1163-1205.

5. Riedl, M.; Truyen, U.; Reese, S.; Hartmann, K. Prevalence of antibodies to canine parvovirus and reaction to vaccination in client-owned, healthy dogs. Vet. Rec. 2015, 177, 597. [CrossRef] [PubMed]

6. Glickman, L.T.; Domanski, L.M.; Patronek, G.J.; Visintainer, F. Breed-related risk factors for canine parvovirus enteritis. J. Am. Vet. Med. Assoc. 1985, 187, 589-594. [PubMed]

7. Houston, D.M.; Ribble, C.S.; Head, L.L. Risk factors associated with parvovirus enteritis in dogs: 283 cases (1982-1991). J. Am. Vet. Med. Assoc. 1996, 208, 542-546. [PubMed]

8. StIKo. Leitlinie zur Impfung von Kleintieren, 4th ed.; Ständige Impfkommission Veterinärmedizin (StIKo Vet) am Friedrich-LoefflerInstitut: Bonn, Germany, 2017.

9. Gray, L.K.; Crawford, P.C.; Levy, J.K.; Dubovi, E.J. Comparison of two assays for detection of antibodies against canine parvovirus and canine distemper virus in dogs admitted to a Florida animal shelter. J. Am. Vet. Med. Assoc. 2012, 240, 1084-1087. [CrossRef] [PubMed]

10. Kim, S.; Kang, M.; Park, H. Comparative study of two point-of-care ezyme-linked immunosorbent assays for the detection of antibodies against canine parvovirus and canine distemper virus. Pak. Vet. 2017, 37, 405-410.

11. Litster, A.L.; Pressler, B.; Volpe, A.; Dubovi, E. Accuracy of a point-of-care ELISA test kit for predicting the presence of protective canine parvovirus and canine distemper virus antibody concentrations in dogs. Vet. J. 2012, 193, 363-366. [CrossRef] [PubMed]

12. Wilhelm, S.; Löwenstein, M.; Truyen, U. Evaluation of an in-house test for detection of canine antibodies against parvovirus. Prakt Tierarzt 2005, 86, 710-717.

13. Parrish, C.R.; Carmichael, L.E.; Antczak, D.F. Antigenic relationships between canine parvovirus type 2, feline panleukopenia virus and mink enteritis virus using conventional antisera and monoclonal antibodies. Arch Virol. 1982, 72, 267-278. [CrossRef] [PubMed]

14. Ottiger, H.P.; Neimeier-Forster, M.; Stark, K.D.; Duchow, K.; Bruckner, L. Serological responses of adult dogs to revaccination against distemper, parvovirus and rabies. Vet. Rec. 2006, 159, 7-12. [CrossRef] [PubMed]

15. Böhm, M.; Thompson, H.; Weir, A.; Hasted, A.M.; Maxwell, N.S.; Herrtage, M.E. Serum antibody titres to canine parvovirus, adenovirus and distemper virus in dogs in the UK which had not been vaccinated for at least three years. Vet. Rec. 2004, 154, 457-463. [CrossRef] [PubMed]

16. Pepe, M.S. The Statistical Evaluation of Medical Tests for Classification and Prediction; Oxford University Press: Oxford, UK, 2003.

17. Deutscher Tierschutzbund, e.V. Der Illegale Handel Mit Hunden und Katzen in Deutschland-Eine Datenauswertung Aus den Jahren 2014 und 2015. Available online: https:/ / docplayer.org/25868869-Der-illegale-handel-mit-hunden-und-katzen-indeutschland-eine-datenauswertung-aus-den-jahren-2014-und-2015.html (accessed on 29 June 2020).

18. Nordbayern. Available online: https://www.nordbayern.de/region/nuernberg/illegaler-welpentransport-bei-erlangen-strafefur-tierarzt-1.8602397 (accessed on 29 June 2020).

19. Schultz, R.D.; Thiel, B.; Mukhtar, E.; Sharp, P.; Larson, L.J. Age and long-term protective immunity in dogs and cats. J. Comp. Path. 2010, 142, 102-108. [CrossRef] [PubMed]

20. Corrain, R.; Di Francesco, A.; Bolognini, M.; Ciucci, P.; Baldelli, R.; Guberti, V. Serosurvey for CPV-2, distemper virus, ehrlichiosis and leishmaniosis in free-ranging dogs in Italy. Vet. Rec. 2007, 160, 91-92. [CrossRef] [PubMed]

21. Vetsurgeon.org. Available online: https://www.vetsurgeon.org/w/veterinary-research/testing-dogs-for-immunity-againstcanine-parvovirus-canine-distemper-virus-and-infectious-canine-hepatitis.aspx (accessed on 29 June 2020).

22. Schoder, D.; Benetka, V.; Sommerfeld-Stur, I.; Kopf, N.; Weissenbacher, E.; Pallan, C.; Walk, K.; Köstl, K. Untersuchungen zum Antikörper-Status gegen Hundestaupe-Virus und Canines Parvovirus-2 bei Hunden in Niederösterreich und Wien nach unterschiedlichen Impfintervallen. Wien Tierärztl. Mschr. 2006, 93, 176-182.

23. Fassisi. Fassisi CanTi Check. 2020. Available online: https://www.fassisi.at/produkte/kleintiere/hunde-fassisi-canti-check/ (accessed on 29 June 2020).

24. Böhm, M. Current vaccination strategies in dogs and cats. Int. Pract. 2009, 31, 2-7. [CrossRef]

25. Burr, P. Serological testing—an alternative to boosters? Vet. Microbiol. 2006, 117, 39-42. [CrossRef] 
26. Cavalli, A.; Bozzo, G.; Decaro, N.; Tinelli, A.; Aliberti, A.; Buonavoglia, D. Characterization of a canine parvovirus strain isolated from an adult dog. New Microbiol. 2001, 24, 239-242.

27. Cavalli, A.; Bozzo, G.; Desario, C.; Camero, M.; Bellacicco, A.L.; De Palo, P.; Decaro, N.; Elia, G.; Buonavoglia, C. Evaluation of the antigenic relationships among canine parvovirus type 2 variants. Clin. Vaccine Immunol. 2008, 15, 534-539. [CrossRef] [PubMed] 